\title{
The Need for Agricultural Water Management in Sub-Saharan Africa
}

\author{
Kbrom Ambachew Gebrehiwot*, Mehari Gidey Gebrewahid \\ Department of Water Resources and Irrigation Engineering, Institute of Technology, Haramaya University, \\ Haramaya, Ethiopia \\ Email: kibe0611@gmail.com,mehari.gidey19@gmail.com
}

Received 20 May 2016; accepted 23 July 2016; published 27 July 2016

Copyright (C) 2016 by authors and Scientific Research Publishing Inc.

This work is licensed under the Creative Commons Attribution International License (CC BY).

http://creativecommons.org/licenses/by/4.0/

(c) (i) Open Access

\section{Abstract}

This paper discusses the current and future conditions that affect water resources and the constraints of water (agricultural) management in sub-Saharan Africa and suggests remedial measures to be considered by policy makers. The pressure on the quantity and quality of water resources is rising in sub-Saharan Africa due to the increased demand of water for agriculture and other purposes as a result of increase in population and food demand. The availability of water is also under threat from changing climate and as a result, water scarcity is expected in many countries in sub-Saharan Africa. On the other hand, the availability of water for agriculture is expected to further shrink due to the increasing demand of water for other purposes like industry, manufacturing and environmental requirement. The current poor efficiency rate of irrigation systems and massive expansion of irrigated area is expected to further exacerbate the water scarcity. Hence, a water management policy focused on maximization of water use efficiency and water productivity should be prioritized in order to meet the food demand of the growing population and cope with water scarcity problems. Engineering and management intervention integrated with strong society awareness and participation is considered very crucial in enhancing water use efficiency and crop water productivity.

\section{Keywords}

Water Scarcity, Water Management, Water Use Efficiency, Water Productivity, Sub-Saharan Africa

\section{Introduction}

World population has risen steadily from a total of 2.5 billion in 1950, to 7.4 billion in 2015 [1]. 16\% of this

\footnotetext{
${ }^{*}$ Corresponding author.
} 
growth comes from sub-Saharan Africa as the region has grown from 180 million to 962 million people from 1950 to 2015. This is about 12 million people a year for the past 65 years or approximately 782 million people in 65 years. According to the 2015 UN Revision, the current world population of 7.4 billion is expected to increase by 2.3 billion people within the next thirty five years, reaching 9.7 billion in 2050, and to further increase to 11.2 billion by 2100. Not surprisingly, by 2050 and 2100, the population of sub-Saharan Africa could be as large as 2.1 and 3.9 billion. This means $77 \%$ of the world population growth from 2015 to 2100 will be from sub-Saharan Africa.

This population growth would inevitably pose additional demand for food [2] [3]. As shown in Figure 1 and Figure 2, majority of countries with higher population growth rate, for example, Ethiopia, Kenya, Uganda and Nigeria, are precisely those showing high level of undernourishment as a result of inadequate food consumption. Nonetheless, these countries are on the verge of development and the food consumption pattern is expected to increase in the near future. The high population growth rate coupled with increased per capita food consumption will highly increase the food demand of the region which cannot be fulfilled simply with the existing production level.

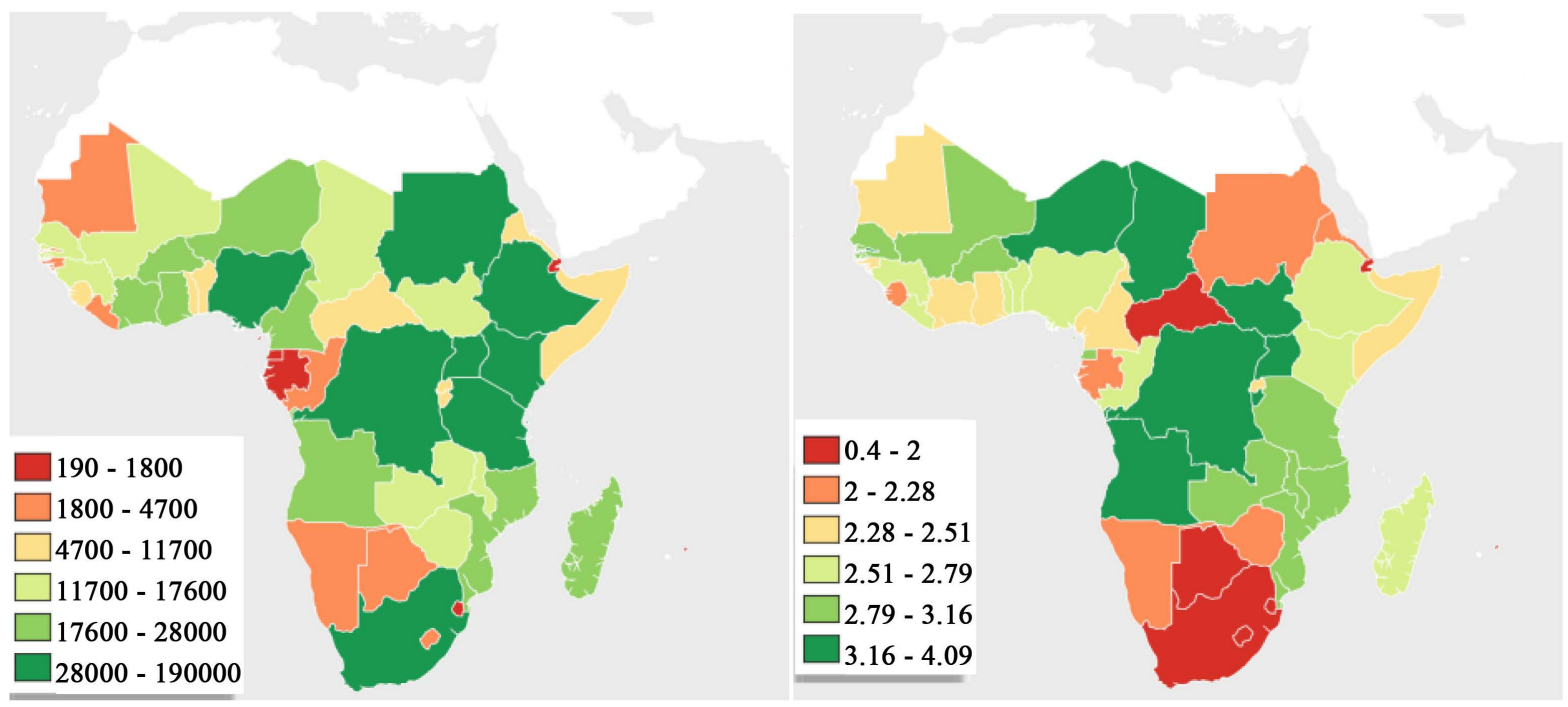

Figure 1. Total population (thousands) (left) and population growth rate (\%) (right) in 2015 (source: United Nations) [1].

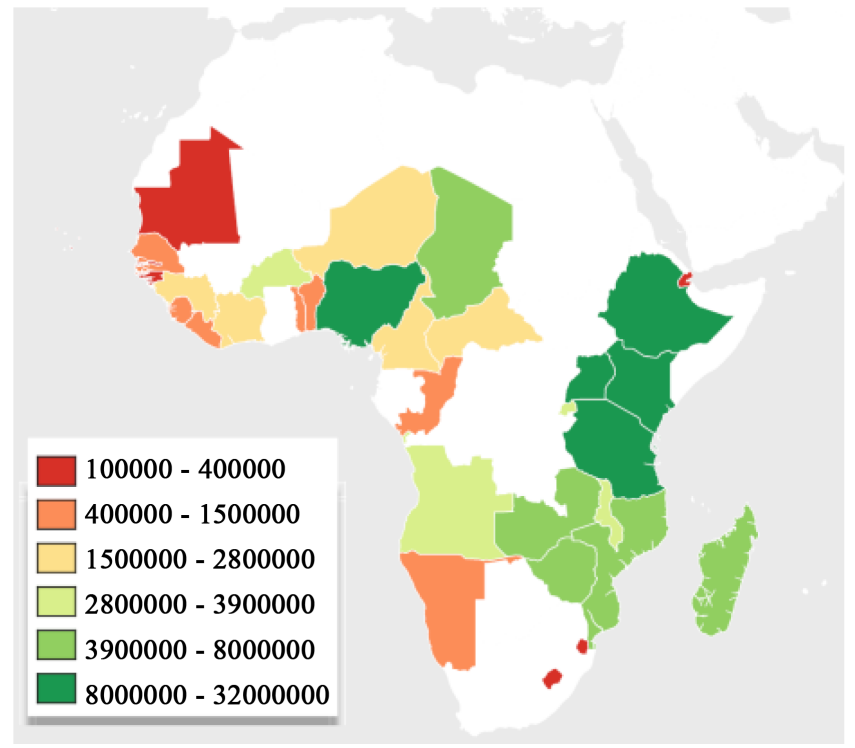

Figure 2. Number of people who are undernourished in 2015 (Source: World Bank [4]). 
In sub-Saharan Africa, food consumption of cereals such as maize, millet, sorghum, and teff (in Ethiopia) is the mainstay of diets [4]. As presented in Table 1, the demand for cereals is higher than the production in many

Table 1. Food (cereals) production and consumption in sub-Saharan Africa (Source: FAO food security data by food groups/items, June 2012).

\begin{tabular}{|c|c|c|c|c|c|c|c|c|c|}
\hline \multirow{2}{*}{ Country } & \multicolumn{3}{|c|}{ Production (kg/person/year) } & \multicolumn{3}{|c|}{ Consumption (Kg/person/Year) } & \multicolumn{3}{|c|}{ Deficit } \\
\hline & 1997 & 2002 & 2007 & 1997 & 2002 & 2007 & 1997 & 2002 & 2007 \\
\hline Angola & 32 & 41 & 45 & 59.9 & 72.3 & 81.0 & -27.9 & -31.3 & -36.0 \\
\hline Benin & 130 & 136 & 130 & 108.0 & 104.0 & 116.1 & 22.0 & 32.0 & 13.9 \\
\hline Botswana & 42 & 16 & 18 & 123.7 & 109.5 & 109.5 & -81.7 & -93.5 & -91.5 \\
\hline Burkina Faso & 215 & 233 & 242 & 223.7 & 219.7 & 233.6 & -8.7 & 13.3 & 8.4 \\
\hline Burundi & 43 & 37 & 35 & 30.3 & 28.8 & 35.8 & 12.7 & 8.2 & -0.8 \\
\hline Cameroon & 86 & 84 & 95 & 89.4 & 96.7 & 108.8 & -3.4 & -12.7 & -13.8 \\
\hline CAR & 35 & 45 & 53 & 41.6 & 48.9 & 57.3 & -6.6 & -3.9 & -4.3 \\
\hline Chad & 121 & 128 & 181 & 108.8 & 118.3 & 144.5 & 12.2 & 9.7 & 36.5 \\
\hline Congo & 4 & 5 & 6 & 44.2 & 75.2 & 77.0 & -40.2 & -70.2 & -71.0 \\
\hline Comoros & 24 & 21 & 21 & 74.5 & 74.5 & 75.2 & -50.5 & -53.5 & -54.2 \\
\hline DRC & 30 & 27 & 23 & 34.7 & 32.9 & 39.8 & -4.7 & -5.9 & -16.8 \\
\hline Djibouti & 0 & 0 & 0 & 111.3 & 125.9 & 138.7 & -111.3 & -125.9 & -138.7 \\
\hline Eritrea & 31 & 31 & 74 & 127.8 & 120.8 & 134.0 & -96.8 & -89.8 & -60.0 \\
\hline Ethiopia & 145 & 132 & 168 & 123.0 & 138.3 & 142.7 & 22.0 & -6.3 & 25.3 \\
\hline Gabon & 25 & 20 & 23 & 94.2 & 101.8 & 109.5 & -69.2 & -81.8 & -86.5 \\
\hline Gambia & 85 & 120 & 117 & 139.8 & 142.7 & 147.5 & -54.8 & -22.7 & -30.5 \\
\hline Ghana & 95 & 87 & 81 & 82.5 & 87.6 & 97.5 & 12.5 & -0.6 & -16.5 \\
\hline Guinea & 143 & 167 & 212 & 127.4 & 127.0 & 127.0 & 15.6 & 40.0 & 85.0 \\
\hline Kenya & 101 & 93 & 100 & 120.1 & 117.5 & 120.5 & -19.1 & -24.5 & -20.5 \\
\hline Lesotho & 103 & 97 & 52 & 216.8 & 221.9 & 227.4 & -113.8 & -124.9 & -175.4 \\
\hline Liberia & 34 & 33 & 35 & 97.8 & 89.1 & 97.5 & -63.8 & -56.1 & -62.5 \\
\hline Madagascar & 137 & 121 & 145 & 111.7 & 117.9 & 129.6 & 25.3 & 3.1 & 15.4 \\
\hline Malawi & 164 & 167 & 177 & 147.8 & 142.4 & 143.1 & 16.2 & 24.7 & 33.9 \\
\hline Mali & 205 & 205 & 274 & 181.0 & 187.6 & 199.7 & 24.0 & 17.4 & 74.3 \\
\hline Mauritania & 78 & 43 & 50 & 164.3 & 159.5 & 169.0 & -86.3 & -116.5 & -119.0 \\
\hline Mauritius & 0 & 0 & 1 & 152.2 & 155.1 & 161.0 & -152.2 & -155.1 & -160.0 \\
\hline Mozambique & 79 & 76 & 66 & 91.6 & 92.7 & 101.5 & -12.6 & -16.7 & -35.5 \\
\hline Niger & 207 & 247 & 281 & 200.0 & 201.1 & 197.5 & 7.0 & 45.9 & 83.5 \\
\hline Nigeria & 185 & 156 & 181 & 136.9 & 133.6 & 145.6 & 48.1 & 22.4 & 35.4 \\
\hline Rwanda & 31 & 33 & 39 & 33.9 & 32.1 & 43.4 & -2.9 & 0.9 & -4.4 \\
\hline Senegal & 100 & 87 & 86 & 154.0 & 152.6 & 164.3 & -54.0 & -65.6 & -78.3 \\
\hline Sierra Leone & 78 & 54 & 136 & 107.3 & 113.2 & 112.1 & -29.3 & -59.2 & 23.9 \\
\hline Sudan & 134 & 115 & 157 & 138.3 & 123.0 & 130.7 & -4.3 & -8.0 & 26.3 \\
\hline Swaziland & 138 & 81 & 50 & 133.6 & 124.1 & 127.8 & 4.4 & -43.1 & -77.8 \\
\hline Tanzania & 132 & 130 & 133 & 106.2 & 106.9 & 104.0 & 25.8 & 23.1 & 29.0 \\
\hline Togo & 142 & 141 & 137 & 116.1 & 118.6 & 123.7 & 25.9 & 22.4 & 13.3 \\
\hline Uganda & 80 & 88 & 84 & 59.5 & 58.8 & 63.5 & 20.5 & 29.2 & 20.5 \\
\hline Zambia & 127 & 90 & 116 & 157.3 & 142.0 & 136.9 & -30.3 & -52.0 & -20.9 \\
\hline Zimbabwe & 192 & 141 & 120 & 148.6 & 144.5 & 157.0 & 43.4 & -3.5 & -37.0 \\
\hline South Africa & 272 & 280 & 227 & 178.5 & 186.2 & 186.9 & 93.5 & 93.9 & 40.1 \\
\hline Namibia & 68 & 59 & 64 & 130.7 & 132.1 & 131.4 & -62.7 & -73.1 & -67.4 \\
\hline Côte d'Ivoire & 70 & 62 & 58 & 96.0 & 89.4 & 93.4 & -26.0 & -27.4 & -35.4 \\
\hline Guinea-Bissau & 111 & 99 & 113 & 139.4 & 146.7 & 146.7 & -28.4 & -47.7 & -33.7 \\
\hline
\end{tabular}


of the sub-Saharan Africa countries. The gap between production and consumption would be more pronounced if other food groups, like starchy roots, vegetables, meat, egg, and others, are considered. To fill this gap and ensure food security dramatic increase in agricultural production is inevitable.

Approximately $40 \%$ of the world's food comes from $17 \%$ of the world's cropland that is irrigated which consumes more than two-third of the world's developed water supplies [5]-[8]. The increase in population and the food demand as well as the changing consumption patterns toward a higher nutrition will be posing challenges to agricultural production [9]. A FAO analysis [10] of 93 developing countries expects agricultural production to increase over the period $1998-2030$ by $49 \%$ in rain fed systems and by $81 \%$ in irrigated systems. According to World Bank [4], agricultural production could nearly triple in sub-Saharan Africa by 2050. In this regard, arable land expansion will remain an important factor in the growth of crop production in the region. In developing countries, it is expected to observe a projected net increase in the arable area of some 107 million ha (from 968 in 2005/07 to 1075 in 2050) of which the 51 million (48\%) is expected to take place in sub-Saharan Africa [4].

In sub-Saharan Africa, the water use efficiency estimated for the year 2005/07 and projected for the year 2050 is 22 and 25 percent respectively, which is by far less than the world average which is 44 and 46 percent respectively [11]. Although, the current water withdrawal for agriculture and other purposes is lower than the total annual renewable water resource, this low water use efficiency will undoubtedly challenge the sustainable use and management of water in the region. Thus, expanding the irrigated area under the present agricultural water management characterized with low irrigation efficiency rates will result in severe water scarcity in the coming decades.

From Figure 3, it is clear that countries with larger total renewable water resources are also having a huge population, resulting in a lower total per capita water availability. In 2014, 16 SSA countries were already under water stress, water scarcity and absolute scarcity conditions according to the "Falkenmark indicator" or "water stress index". Based on the per capita usage, the water conditions in an area can be categorized as: no stress (> $1700 \mathrm{~m}^{3}$ per capita), stress (1000 - $1700 \mathrm{~m}^{3}$ per capita), scarcity $\left(500-1000 \mathrm{~m}^{3}\right.$ per capita), and absolute scarcity $\left(<500 \mathrm{~m}^{3}\right.$ per capita) [12]. As shown in Table 2, the per capita renewable water resource was declining with time due to the increase in population. As predicted by Falkenmark [13], most of the East and some of the South African countries have already been water stressed. The projection by Falkenmark [13] indicates that eight of the East and some of the South African countries will arrived at absolute scarcity by 2025 and five of the West African countries will become at least water stressed in the early decades of the twenty first century.

Not surprisingly, the water resources of some countries had already been declined and changed from no stress to stress and scarcity levels. For instance, in 2007, Comoros, Nigeria and Uganda were under no stress condition. However, in 2012 and 2014, their water resource was declined and changed to the stress category. Similarly,

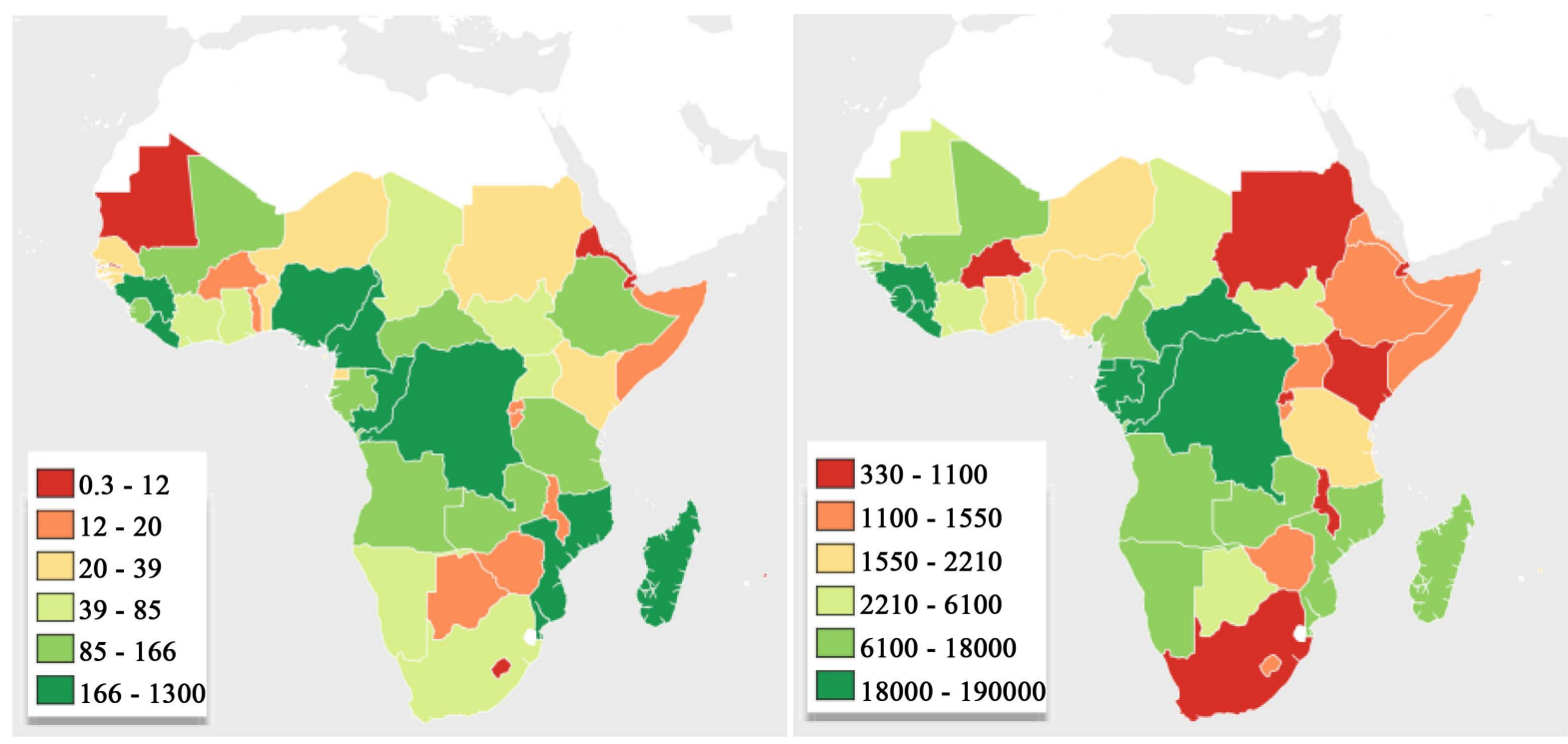

Figure 3. Total renewable water resources, BCM, (left) and total renewable water resources per capita, $\mathrm{m}^{3} / \mathrm{person} / \mathrm{yr}$, (right) in 2014 (Source: FAO Aquastat 2015). 
Table 2. Per capita renewable water resources (Source: FAO Aquastat 2015).

\begin{tabular}{cccc}
\hline Country & \multicolumn{3}{c}{ Water resources $\left(\mathbf{m}^{3} / \mathbf{p e r} / \mathbf{y r}\right)$} \\
\cline { 2 - 4 } Djibouti & $\mathbf{2 0 0 7}$ & $\mathbf{2 0 1 2}$ & $\mathbf{2 0 1 4}$ \\
Kenya & 375.50 & 348.80 & 339 \\
Burkina Faso & 813.20 & 711.00 & 674 \\
South Africa & 948.40 & 820.20 & 775 \\
Malawi & 1035.00 & 980.20 & 966 \\
Sudan & 1260.00 & 1086.00 & 1027 \\
Rwanda & No data & 1016.00 & 975 \\
Eritrea & 1340.00 & 1161.00 & 1099 \\
Burundi & 1404.00 & 1193.00 & 1119 \\
Ethiopia & 1506.00 & 1273.00 & 1196 \\
Lesotho & 1517.00 & 1330.00 & 1264 \\
Zimbabwe & 1545.00 & 1473.00 & 1440 \\
Somalia & 1570.00 & 1457.00 & 1370 \\
Comoros & 1650.00 & 1442.00 & 1360 \\
Nigeria & 1896.00 & 1671.00 & 1596.00 \\
Uganda & 1944.00 & 1695.00 & 1603.00 \\
& 1956.00 & 1654.00 & 1547.00 \\
\hline & & & \\
\hline
\end{tabular}

South Africa's water resources status was changed from stress category in 2007 to scarcity category in 2014. Nevertheless, the attention given to water management in sub-Saharan Africa is still inadequate. As a result, over exploitation of water resources by different sectors is shadowing the efforts made to ensure sustainable water use in the region. Considering the global figure, withdrawal of water by about a quarter of the irrigated systems is above the regeneration rate [14]. This coupled with the poor property rights specifications on water resources and inefficient irrigation practices is creating a potential for serious water shortages. Moreover, with the growing demand of water for industry, manufacturing and urban sectors, combined with environmental problems, water available for agriculture will decrease in the future [15]-[18]. On the other hand, as irrigation (agriculture) is vitally important in meeting the food and fiber needs for a rapidly expanding world population, the demand for agricultural water is continuously growing [3] [7] [19]. Additionally, the rapid growth in population and income requires large water investments and financing that result in further pressure on the quantity and quality of water resources [20]. The problem of providing the food for a much greater world population, therefore, becomes focused on the area of growing more on existing water and land resources [21].

\section{What Are the Areas of Improvement in Water Management?}

Many sub-Saharan Africa countries must develop more than twice the amount of water they currently use to meet reasonable future requirements [21]. For instance, Ethiopia must double its cereal production by 2025 to meet the food needs of its rapidly growing population and secure food self sufficiency which in its turn escalate its agricultural water demand [22]. Considering the fact that $90 \%$ of staple food for sub Saharan Africa comes from rain-fed farming systems, [23] cited in [24] recommended that much greater emphasis will have to be given to increasing the productivity of global rain-fed agriculture. However, rain-fed agriculture remains risky because of spatial and temporal variability in rainfall, water scarcity, droughts, soil erosion by wind and water, low investment, or high population pressure [25]. Moreover, there is a significant difference in crop yields between irrigated and rain-fed agriculture. In developing countries, grain yields from rain-fed agriculture are $1.5 \mathrm{t} / \mathrm{ha}$ compared to $3.1 \mathrm{t} / \mathrm{ha}$ from irrigated agriculture on average [26] cited in [9]. Hence, due attention will have to be given to better management of water resources in both irrigated and rain-fed agriculture. In this regard, instead of trying to supply the growing demand for water with new sources, improvement in the water-use efficiency 
should be the main focus in water-management policies [18] [27]. To increase water-use efficiency, several practices can be adopted. Water-saving techniques, advances in irrigation technology (e.g., drip irrigation) and management, leaving crop residues on the soil surface and planting cover crops and adequate tillage practices are considered as potential measures to improve water use efficiency and adapt to climate change impacts [9] [28]-[30]. However, with the limited and shrinking water availability, the increasing water requirement, due to expansion of irrigable lands as a result of growing population and food demand, cannot be reversed by improving the water use efficiency only. Hence, increasing water productivity deserves much attention as well. Increasing water productivity means either to produce the same yield with less water resources or to obtain higher crop yields with the same water resources [31] which would enable growing more food and hence feeding the ever increasing population or gaining more benefits with less water [32]. In its broadest sense, it reflects the objectives of producing more food, income, livelihood and ecological benefits at less social and environmental cost per unit of water consumed [33].

Sub-Saharan Africa countries, often characterized with low yield levels and large on-farm water losses resulting in poor water use efficiencies, have a promising potential for improvements in water productivity through introduction of agronomic or engineering measures [15] [33]. An important means of achieving increased water productivity will be to get more from the amount of water that is beneficially depleted by agriculture which can be achieved by introducing different agronomic, engineering and management technologies such as changing crop varieties, crop substitution, deficit, supplemental or precision irrigation [7] [16]. The next sections discuss small holder drip irrigation and water pricing as examples of the engineering and management techniques to improve water productivity and, of course, water use efficiency.

\subsection{Small Holder Drip Irrigation System}

Drip irrigation's combination of water savings and yield increases typically produces at least a doubling of water productivity, yield per unit water, and makes it a leading technology in the global challenge of boosting crop production in the face of serious water constraints [34] cited in [35]. However, due to its high capital cost, particularly for the poor farmers, the conventional drip irrigation is generally not widely used on a global scale and accounts for less than $0.1 \%$ of irrigated land worldwide [36]. Nonetheless, smallholders drip irrigation system attempts to retain the benefits of conventional systems while removing the factors that prevent their adoption by poor smallholders: purchase cost, the need for a pressurized supply, the associated pumping costs, and the complexity of operation and maintenance. It can help solve water management problems faced by smallholder farmers by making it easier and simpler to supply the right amount of water to their crops at the right place and at the right time [37]. Drip irrigation used about $35 \%$ of the water used by the surface irrigation systems thus giving much higher water use efficiencies [38]. It was also concluded by [38] that low cost drip systems achieved water saving of more than 50\% compared to surface irrigation systems. Further results from field trials demonstrate that affordable smallholders drip systems easily pay for themselves in one growing season, and stimulate shifts to more intensive agricultural practices by small farmers [39]. Implementation of this technology might help improve livelihoods of individual farmers or small communities and is mentioned promising in the context of poverty alleviation which is the number one enemy of many sub-Saharan Africa countries [36].

Despite the higher potential for smallholder drip irrigation and other small scale irrigation technologies as supplementary irrigation for millions of people and to achieve household food security, the use of the technology has hardly begun in many sub-Saharan Africa countries. With proper marketing and proper agronomic and technical support low cost irrigation technologies can be adopted by smallholder farmers to change family lifestyles, increase people's incomes, create employment and go a long way towards food security and improved nutrition [38]. However, recent literatures argue that the success of the technology is interpreted through development agencies lenses and with the intention of continuing involvement in future projects [40] [41]. Hence, it is recommended to get the technology tested for its efficiency, productivity and social acceptance by farmers and independent researchers before its introduction and distribution to the vast agrarian population.

\subsection{Water Pricing}

Water pricing has become a key issue in both the developed and developing world. It is designed taking into account various objectives which are oftentimes more and more difficult to achieve due to environmental constraints, increased water demand, climate change and economic crisis which impacts all incomes (households, 
farmers, industries). The three main objectives of water pricing are balancing water budget, allowing water access, and inciting users to save water [42]. Achieving these objectives directly leads to a better water resource management which could help us in coping with the scarce and still shrinking water resource. [20] reported that pricing of water and water services are an acceptable practice that may result in better conservation and sustainable management of water. This is because higher prices for water use would encourage its more rational use by agricultural users and provide funds for investing in infrastructure which are two necessary conditions to avoid risk of water shortage [43].

Although, water pricing has long been practiced in some developed countries, it has been rarely or hardly implemented in sub Saharan Africa. The question here would be "how to introduce water pricing for the first time in an area where water has been accessed for free?" and "on what basis to effect the pricing?”. In principle, there are multiple pricing patterns for irrigation water. The most common pricing systems are based on volume, area, electricity consumption (for groundwater based irrigation), type of irrigation or crop and block rate pricing structure [44]. The experience of the countries which have already implemented different pricing systems can be taken as a bench mark to choose better pricing approach in a particular area. The area pricing system, modified according to the crop or irrigation techniques, does not encourage water saving for a given choice of crop or irrigation technique, but it does have more effect on the choice of which crops to irrigate or which irrigation technique to adopt [45]. Pricing systems based on volume, volumetric pricing, and block rate pricing structure are known for their effect on high water savings. [46] cited in [47] estimated a $40 \%$ reduction in irrigation water demand associated with the increasing block rate structure.

Water pricing alone will not always be a sufficient incentive for users to enhance water saving and improve irrigation performance [45]. Thus, due consideration is needed to be given to water distribution and control. Rational water use has to be achieved by careful control of distribution and by allocations that broadly meet crop requirements. In this regard, it is required to enhance understanding of water scarcity among irrigators and encourage more efficient water use. It is also worthy to ensure better control over the supply of water as it can reduce wastage of water associated with excess amounts of water flowing through uncontrolled canals and ungated turnouts onto fields and into drainage channels [48].

\section{Conclusion}

Water scarcity is becoming severe and the availability of water for agriculture is dwindling due to increasing population and food demand, changing climate, expansion of industries and manufacturing. In order to sustain their economy and feed their population, sub-Saharan Africa countries should implement sound, feasible and implementable water management policy that can help in obtaining more production from the existing resources, land and water, through maximization of water use efficiency and crop water productivity. It is, thus, wise to develop a set of engineering and management interventions such as water-saving techniques, improved irrigation management, supplemental or precision irrigation, water pricing and better agronomy. Before implementation, however, the intervention measure should be tested through independent and participatory research. Above all, farmers, government and non-governmental organizations should cautiously evaluate the feasibility of the intervention measures and proper awareness should be given to the farming community.

\section{References}

[1] United Nations (2015) World Population Prospects: The 2015 Revision. DVD Edition, Department of Economic and Social Affairs, Population Division. United Nations, New York.

[2] Rockström, J., Barron, J. and Fox, P. (2003) Water Productivity in Rain-Fed Agriculture: Challenges and Opportunities for Smallholder Farmers in Drought-Prone Tropical Agroecosystems. In: Kijne, J.W., Barker, R. and Molden, D, Eds., Water Productivity in Agriculture: Limits and Opportunities for Improvement, CABI, Wallingford, 145-162. http://dx.doi.org/10.1079/9780851996691.0145

[3] Playan, E. and Mateos, L. (2006) Modernization and Optimization of Irrigation Systems to Increase Water Productivity. Agricultural Water Management, 80, 100-116. http://dx.doi.org/10.1016/j.agwat.2005.07.007

[4] World Bank (2016) Health Nutrition and Population Statistics. World Bank, Washington DC.

[5] Shiklomanov, I.A. (2000) Appraisal and Assessment of World Water Resources. Water International, 25, 11-32. http://dx.doi.org/10.1080/02508060008686794

[6] Molden, D. (1997) Accounting for Water Use and Productivity. SWMI Paper, International Water Management Insti- 
tute, Colombo.

[7] Howell, T.A. (2001) Enhancing Water Use Efficiency in Irrigated Agriculture. Agronomy Journal, 93, $281-289$. http://dx.doi.org/10.2134/agronj2001.932281x

[8] Gleick, P.H. (2002) Water Management: Soft Water Paths. Nature, 418, 373. http://dx.doi.org/10.1038/418373a

[9] Heumesser, C., et al. (2013) Current State and Future Potential of Global Food Production and Consumption. In: Rengel, Z., Ed., Improving Water and Nutrient-Use Efficiency in Food Production Systems, John Wiley \& Sons, Inc., Hoboken,, 1-19. http://dx.doi.org/10.1002/9781118517994.ch1

[10] Bruinsma, J. (2003) World Agriculture: Towards 2015/2030. An FAO Perspective. Earthscan Publications Ltd., London.

[11] Bruinsma, J. (2009) The Resource Outlook to 2050. Paper Presented at the Expert Meeting on How to Feed the World in 2050, Rome, 24-26 June 2009.

[12] Falkenmark, M., Lundqvist, J. and Widstrand, C. (1989) Macro-scale Water Scarcity Requires Micro-Scale Approaches. Natural Resources Forum, 13, 258-267. http://dx.doi.org/10.1111/j.1477-8947.1989.tb00348.x

[13] Falkenmark, M. (1989) The Massive Water Scarcity Now Threatening Africa: Why Isn't It Being Addressed? Ambio, 18, 112-118.

[14] Ghanem, H. (2008) The State of Food Insecurity in the World, 2008: High Food Prices and Food Security: Threats and Opportunities. Food and Agriculture Organization of the United Nations (FAO), Rome.

[15] Kijne, J.W., Barker, R. and Molden, D. (2003) Improving Water Productivity in Agriculture: Editors’ Overview. In: Kijne, J.W., Barker, R. and Molden. D., Eds., Water Productivity in Agriculture: Limits and Opportunities for Improvement, CABI, Wallingford, xi-xix.

[16] Molden, D. and Sakthivadivel, R. (1999) Water Accounting to Assess Use and Productivity of Water. International Journal of Water Resources Development, 15, 55-71. http://dx.doi.org/10.1080/07900629948934

[17] De Fraiture, C., et al. (2007) Looking Ahead to 2050: Scenarios of Alternative Investment Approaches. In: Molden, D., Ed., Water for Food, Water for Life: A Comprehensive Assessment of Water Management in Agriculture, Earthscan/IWMI, London/Colombo, 91-145.

[18] Garnett, T.P. and Rebetzke, G.J. (2013) Improving Crop Nitrogen Use in Dryland Farming. Improving Water and Nutrient-Use Efficiency in Food Production Systems, Chap. 8, 123-144. http://dx.doi.org/10.1002/9781118517994.ch8

[19] Kumar, M.D., Sivamohan, M. and Bassi, N. (2012) Water Management, Food Security and Sustainable Agriculture in Developing Economies. Routledge, Abingdon-on-Thames.

[20] Dinar, A., Pochat, V. and Albiac-Murillo, J. (2015) Water Pricing Experiences and Innovations. Global Issues in Water Policy. Springer International Publishing, Gewerbestrasse. http://dx.doi.org/10.1007/978-3-319-16465-6

[21] Seckler, D.W. (1998) World Water Demand and Supply, 1990 to 2025: Scenarios and Issues. Vol. 19, Iwmi, Colombo, Sri Lanka.

[22] Awulachew, S.B., et al. (2005) Experiences and Opportunities for Promoting Small-Scale/Micro Irrigation and Rainwater Harvesting for Food Security in Ethiopia. International Water Management Institute, Addis Ababa.

[23] Rosegrant, M.W., Cai, X. and Cline, S.A. (2002) World Water and Food to 2025: Dealing with Scarcity. International Food Policy Research Institute.

[24] Cooper, P., Dimes, J., Rao, K.P.C., Shapiro, B., Shiferaw, B. and Twomlow, S. (2008) Coping Better with Current Climatic Variability in the Rain-Fed Farming Systems of Sub-Saharan Africa: An Essential First Step in Adapting to Future Climate Change? Agriculture, Ecosystems \& Environment, 126, 24-35. http://dx.doi.org/10.1016/j.agee.2008.01.007

[25] Wani, S.P., Rockström, J. and Oweis, T.Y. (2009) Rainfed Agriculture: Unlocking the Potential. Vol. 7, CABI, Wallingford. http://dx.doi.org/10.1079/9781845933890.0000

[26] Rosegrant, M.W., et al. (2002) The Role of Rainfed Agriculture in the Future of Global Food Production. Environment and Production Technology Division, International Food Policy Research Institute.

[27] Gleick, P.H. (2003) Global Freshwater Resources: Soft-Path Solutions for the 21st Century. Science, 302, $1524-1528$. http://dx.doi.org/10.1126/science.1089967

[28] Hoanh, C.T., Johnston, R. and Smakhtin, V. (2015) Climate Change and Agricultural Development: A Challenge for Water Management. In: Hoanh, C.T., Johnston, R. and Smakhtin, V., Eds., Climate Change and Agricultural Water Management in Developing Countries, CABI, Wallingford, 1.

[29] Fuchs, M. (2007) Impact of Research on Water Use for Irrigation in Israel. Irrigation Science, 25, 443-445. http://dx.doi.org/10.1007/s00271-006-0050-z

[30] Stanhill, G. (1992) Irrigation in Israel: Past Achievements, Present Challenges and Future Possibilities. Water Use Ef- 
ficiency in Agriculture: Proceedings of the Binational China-Israel Workshop, Beijing, 22-26 April 1991, 63-77.

[31] Zwart, S.J. and Bastiaanssen, W.G. (2004) Review of Measured Crop Water Productivity Values for Irrigated Wheat, Rice, Cotton and Maize. Agricultural Water Management, 69, 115-133. http://dx.doi.org/10.1016/j.agwat.2004.04.007

[32] Yihun, Y.M., Haile, A.M., Schultz, B. and Erkossa, T. (2013) Crop Water Productivity of Irrigated Teff in a Water Stressed Region. Water Resources Management, 27, 3115-3125. http://dx.doi.org/10.1007/s11269-013-0336-x

[33] Molden, D., et al. (2009) Improving Agricultural Water Productivity: Between Optimism and Caution. Agricultural Water Management, 97, 528-535. http://dx.doi.org/10.1016/j.agwat.2009.03.023

[34] Postel, S. (1999) Pillar of Sand: Can the Irrigation Miracle Last? W.W. Norton \& Company, New York.

[35] Postel, S., Polak, P., Gonzales, F. and Keller, J. (2001) Drip Irrigation for Small Farmers. Water International, $26,3-13$. http://dx.doi.org/10.1080/02508060108686882

[36] Mehari Haile, A., Depeweg, H. and Stillhardt, B. (2003) Smallholder Drip Irrigation Technology: Potentials and Constraints in the Highlands of Eritrea. Mountain Research and Development, 23, 27-31. http://dx.doi.org/10.1659/0276-4741(2003)023[0027:SDIT]2.0.CO;2

[37] Stillhardt, B., Ghebru, B. and Mehari, A. (2003) Small-Scale Micro Irrigation in Eritrea. A Feasibility Study on the Introduction of Affordable Micro Irrigation Technology in Eritrea. Environment (CDE), University of Bern, Hochschulstrasse.

[38] Maisiri, N., Senzanje, A., Rockstrom, J. and Twomlow, S.J. (2005) On Farm Evaluation of the Effect of Low Cost Drip Irrigation on Water and Crop Productivity Compared to Conventional Surface Irrigation System. Physics and Chemistry of the Earth, Parts A/B/C, 30, 783-791. http://dx.doi.org/10.1016/j.pce.2005.08.021

[39] Postel, S. (2000) Entering an Era of Water Scarcity: The Challenges Ahead. Ecological Applications, 10, 941-948. http://dx.doi.org/10.1890/1051-0761(2000)010[0941:EAEOWS]2.0.CO;2

[40] Wanvoeke, J., Venot, J.-P., De Fraiture, C. and Zwarteveen, M. (2015) Smallholder Drip Irrigation in Burkina Faso: The Role of Development Brokers. The Journal of Development Studies, 52, 1019-1033.

[41] Venot, J.-P. (2016) A Success of Some Sort: Social Enterprises and Drip Irrigation in the Developing World. World Development, 79, 69-81. http://dx.doi.org/10.1016/j.worlddev.2015.11.002

[42] Montginoul, M., Loubier, S., Barraqué, B. and Agenais, A.-L. (2015) Water Pricing in France: Toward More Incentives to Conserve Water. In: Dinar, A., Pochat, V. and Albiac-Murillo, J., Eds., Water Pricing Experiences and Innovations, Springer International Publishing, Gewerbestrasse, 139-160. http://dx.doi.org/10.1007/978-3-319-16465-6_8

[43] De Andrade Resende Filho, M., Correa, J.S.O. and de Oliveira Torres, M. (2015) Water Pricing in Brazil: Successes, Failures, and New Approaches. In: Dinar, A., Pochat, V. and Albiac-Murillo, J., Eds., Water Pricing Experiences and Innovations, Springer International Publishing, Gewerbestrasse, 41-61. http://dx.doi.org/10.1007/978-3-319-16465-6_3

[44] Che, Y. and Shang, Z. (2015) Water Pricing in China: Impact of Socioeconomic Development. In: Dinar, A., Pochat, V. and Albiac-Murillo, J., Eds., Water Pricing Experiences and Innovations, Springer International Publishing, Gewerbestrasse, 97-115. http://dx.doi.org/10.1007/978-3-319-16465-6 6

[45] Chohin-Kuper, A., Rieu, T. and Montginoul, M. (2003) Water Policy Reforms: Pricing Water, Cost Recovery, Water Demand and Impact on Agriculture. Lessons from the Mediterranean Experience. Proceedings of the Water Pricing Seminar, Agencia Catalana del Agua and World Bank Institute, Barcelona, 30 June -2 July 2003, 1-9.

[46] Pike, T., et al. (2007) Does Pricing Water Reduce Agricultural Demand? An Example from British Columbia. Sustainable Development Briefing Note. Government of Canada, Policy Research Initiative. http://www.policyresearch.gc.ca

[47] Renzetti, S. and Dupont, D.P. (2015) Water Pricing in Canada: Recent Developments. In: Dinar, A., Pochat, V. and Albiac-Murillo, J., Eds., Water Pricing Experiences and Innovations, Springer International Publishing, Gewerbestrasse, 63-81. http://dx.doi.org/10.1007/978-3-319-16465-6_4

[48] Molle, F. and Berkoff, J. (2007) Water Pricing in Irrigation: The Lifetime of an Idea. In: Molle, F. and Berkoff, J., Eds., Irrigation Water Pricing: The Gap between Theory and Practice, CABI, Wallingford, 1-20. 


\section{Submit or recommend next manuscript to SCIRP and we will provide best service for you:}

Accepting pre-submission inquiries through Email, Facebook, LinkedIn, Twitter, etc.

A wide selection of journals (inclusive of 9 subjects, more than 200 journals)

Providing 24-hour high-quality service

User-friendly online submission system

Fair and swift peer-review system

Efficient typesetting and proofreading procedure

Display of the result of downloads and visits, as well as the number of cited articles

Maximum dissemination of your research work

Submit your manuscript at: http://papersubmission.scirp.org/ 